\title{
Implementation of Authentic Assessment in Science Learning at Indonesian Schools
}

\author{
Didik Setyawarno $^{1^{*}}$, Atik Kurniawati ${ }^{2}$ \\ ${ }^{1}$ Study Program of Science Education, Faculty of Mathematics and Natural Sciences, Yogyakarta State University \\ ${ }^{2}$ Study Program of Biology Education, Faculty of Mathematics and Natural Sciences, Yogyakarta State University \\ Corresponding Author. Email: didiksetyawarno@uny.ac.id
}

\section{Keywords:}

authentic

assessment and

science learning

\section{ABSTRACT}

\begin{abstract}
This article is intended for students of science education, science teachers and observers of science education. The article aims to discuss about authentic assessment in science teaching in schools. In addition, this article is associated with the implementation of the curriculum of 2013 in schools. Aspects reviewed in the article include: the concepts of authentic assessment, assessment in the curriculum of 2013, procedures of authentic assessment, and the application of authentic assessment in science learning. Readers after reading this article are expected to have an understanding of the concepts of authentic assessment, assessment in the curriculum of 2013, procedures in authentic assessment, and the application of an assessment of authentic in science learning.
\end{abstract}

C2018 JSER. Yogyakarta State University

\section{INTRODUCTION}

The problem of science education in our country almost never stops, even new problems continue to emerge in education. These issues will make all figures involved in science education think further and deeply to overcome them. The problem in teaching science has led to a $5 \mathrm{M}$ learning model that follows a scientific approach to learning that is in accordance with the nature of science itself. In addition, the assessment that was initially still conventional in the sense of emphasizing cognitive aspects has led to an authentic assessment that covers all aspects of students in terms of cognitive, affective, and psychomotor aspects.

Authentic assessment is seen as an alternative in the implementation or implementation of the 2013 curriculum at the school level from aspects of learning outcomes assessment. Actually, innovation in the field of education has been sought by the government, both at the level of basic education and higher education in order to improve the quality of education in our country. In addition, many innovations in learning have been carried out such as learning through computer simulations, active learning methods of students or process skills approaches. But it has not shown a significant increase in results.

Many efforts have been taken by the government in order to improve the quality of education, especially at the level, including the allocation of education funds, changes in curriculum, improvement of the quality of primary school teachers, provision of learning facilities and infrastructure and learning resources. In addition, there are several determinants of success in improving the quality of education at the primary level, including: the learning process, the process of assessment and evaluation of learning, teachers, students, learning facilities and infrastructure and how to evaluate the teacher, the social environment of students in school, school curriculum and learning resources.

Assessment and evaluation are an integral part of the science learning process in the classroom. A teacher is unlikely to know whether his students have understood and examined the concepts taught except with the evaluation and evaluation of learning outcomes. Likewise, the process of evaluating and evaluating learning outcomes that are not good will not produce important information related to the learning process and competencies that are controlled by students. Nyoman Dantes (2008: 1) states that relevant education must rely on four pillars of education, namely (1) learning to know, namely students learn knowledge, (2) learning to do, namely students use their knowledge to develop skills, (3) learning to be, namely students learn to use 
their knowledge and skills to live, and (4) learning to live together, that is, students learn to realize that there is mutual dependence so that mutual respect is needed between fellow human beings. The four pillars need to be used as a reference in the learning process and assessment of learning outcomes of students in learning science.

The application of authentic assessment has a suitability with the scientific approach to learning according to the demands of the 2013 curriculum which is able to illustrate the improvement of student learning outcomes, both in order to observe, reason, try, build networks, and others. The assessment aims to measure various skills in various contexts that describe the conditions in the real world where these skills are used. Authentic Assessment is a signi fi cantly meaningful measurement of student learning outcomes for the realm of attitudes, skills and knowledge (Kemendikbud, 2014). The application of an authentic assessment as a 2013 Curriculum Assessment Standard which is expected to have a positive impact on Indonesian education in the future, in fact gets various perceptions and criticisms in its development (Widowati, Aminah, \& Cari, 2016: 9). Authentic assessment in the implementation of the 2013 curriculum is based on attitude competency assessment through observation, self-assessment, peer evaluation by students and journals, knowledge through written tests, tests, oral, and assignments, skills through performance appraisal, namely assessment requires students to demonstrate a particular competency using practice, project and portfolio assessment tests

This article aims to discuss the authentic assessment of science learning in schools. In addition this article is linked to the implementation of the 2013 curriculum in schools. Aspects examined in the article include: the nature of authentic assessment, assessment in the 2013 curriculum review, procedures or stages in authentic assessment, and application of authentic assessments in science learning.

\section{METHODS}

The purposes of this article is to identify how to implement authentic assessment for science learning in Indonesian School. Identification is based on the descriptive research using some journal publications and books from Ministry of Education and Culture in Indonesia which is held science education study program.

\section{RESULTS}

Assessment is central to teaching and learning (Fook and Sidhu, 2010, p.153). Based on this statement assessment or assessment is the heart of learning and teaching activities. Information from the assessment results is needed to make decisions about the ability of learners in learning, their position in learning achievement. Full assessment can be understood as a process of gathering and processing information to measure the achievement of student learning outcomes. The collection of information was taken through various assessment techniques, using various instruments, and came from various sources (Kemdikbud, 2017, p.7). In the implementation of the assessment must be carried out effectively, so that what is considered right on target. The information that has been collected as much as possible with various efforts must be able to provide an overview of the competencies that have been mastered and that have not been mastered by students must be accurate to produce decisions.

\section{Assessment in The 2013 Curriculum}

The 2013 curriculum is basically a competency-based curriculum. The important thing that must be considered when carrying out the assessment in 2013 Curriculum is the determination of minimum completeness (MCC), predicate, remedial and Enrichment (Kemdikbud, 2017, p.15). One of the assessment characteristics in the 2013 curriculum is authentic. Authentic assessment is carried out to measure the achievement of competencies in a holistic manner which consists of aspects of attitudes, knowledge, and skills assessed simultaneously in accordance with real conditions. Assessment is carried out to determine the achievement of students' competencies that are associated with the real situation rather than the world of school. Therefore, various forms and techniques of assessment are used in assessing them. Authentic assessment does not only measure what is known by students, but rather emphasizes measuring what students can do.

The 2013 curriculum states that assessments in junior high schools for all basic competencies include attitudes, knowledge and skills. Attitude assessment is intended as an assessment of the behavior of students in the process of learning curricular and extracurricular activities, which include spiritual and social attitudes. Attitude assessment has different characteristics from the assessment of knowledge and skills, so the assessment techniques used are also different. In this case, attitude assessment is more intended to foster behavior in accordance with character in the framework of the formation of students' character in accordance with the learning process. Assessment of spiritual attitudes (core competency 1 or KI-1), including:

a. obedience to worship;

b. behave gratitude;

c. pray before and after doing activities; and

d. tolerance in worship. 
This spiritual attitude can be added according to the characteristics of the education unit. Assessment of social attitudes (core competency 2 or KI-2) includes:

a. honest is behavior based on the effort to make himself as a person who can always be trusted in words, actions, and work;

b. discipline, namely actions that show orderly behavior and comply with various provisions and regulations;

c. responsibility is the attitude and behavior of students to carry out their duties and obligations, which should be done to themselves, society, environment, country, and God Almighty;

d. polite.

Knowledge assessment (core competency 3 or KI-3) is done by measuring students' mastery that includes factual, conceptual, and procedural knowledge in various stages of the thinking process (Kemdikbud, 2017, p.58). The KI-3 rating uses numbers with a range of achievements of 0 to 100 and descriptions. Descriptions are made using motivational sentences with a choice of words / phrases that are positive. The description contains some very good and / or good knowledge controlled by students and whose mastery is not optimal. In Permendikbud Number 21 of 2016 concerning Content Standards for Primary and Secondary Education stated explicitly that the learning outcomes of the knowledge domain follow Bloom's Taxonomy which has been revised by Lorin Anderson and David Krathwohl (Anderson \& Krathwohl, 2001, p.30) which states as follows.

"The categories range from the cognitive processes most commonly found in objectives, those associated with remember, through understand and apply, to those less frequently found, Analyze, evaluate, and create".

The statement states that the latest taxonomic level is remembering, understanding, applying, analyzing, evaluating, and creating. In addition Lorin Anderson and David Krathwohl also mean that the four types in the knowledge dimension factual, conceptual, procedural, and metacognitive (Anderson \& Krathwohl, 2001, p.30). The domain of knowledge is a combination of knowledge dimensions classified into factual, conceptual, procedural, and metacognitive with the dimensions of cognitive processes arranged hierarchically starting from remembering, understanding, applying, analyzing, evaluating, and creating.

Skill assessment is an assessment carried out to measure the ability of students to apply knowledge in carrying out certain tasks in various contexts in accordance with indicators of achievement of competencies (Kemdikbud, 2017, p.78). Assessment of these skills includes the realm of thinking and acting. Skills in the realm of thinking include skills in reading, writing, counting, and writing. Skills in the realm of acting include, among others, using, parsing, assembling, modifying, and making. Skills assessment can be done with a variety of techniques, including assessment of practice, product assessment, project appraisal, portfolio assessment, and other techniques such as written tests. Skill assessment techniques used are chosen according to the characteristics of basic competency (KD) in core competency 4 (KI-4).

\section{Authentic Assessment}

Authentic assessment is a valuation approach that requires students to display attitudes, using knowledge and skills acquired from learning in real situations (real world) (Kemdikbud, 2015, p.6). In other hand Gulikers, Bastiaens, \& Kirscher define authentic assessment:

"An assessment requiring students to demonstrate the same (kind of) competencies, or combinations of knowledge, skills and attitudes, that they need to apply in the criterion situation in professional life" (Gulikers, Bastiaens, \& Kirscher, 2004, p.5).

The definition states that authentic judgment requires students to demonstrate the same competencies or the combination of knowledge, skills, and attitudes they need to apply in a given situation in a professional life. Authentic assessment emphasizes the practical application of real-world settings (Fook \& Shidu, 2010, p.154). In addition Mueller defines that authentic assessments as direct measures of students' formal knowledge and skills through education to perform authentic tasks (Mueller, 2005, p.3). Based on the description it can be understood that authentic assessment is an assessment of all domains in learning that includes both knowledge (cognitive) and skills (psychomorphic and affective) that are directly related to the real life of students who are assessed directly by the teacher.

Authentic is one of the characteristics of assessment in accordance with the 2013 curriculum based on Permendikbud Number 66 of 2013. The Minister of Education and Culture stated that authentic assessment is a comprehensive assessment to assess starting from input, process, and output of learning. In this case, authentic assessment is carried out to measure achievement of competence holistically which includes aspects of attitudes, knowledge, and skills assessed simultaneously in accordance with real conditions. The assessment in the 2013 curriculum refers to Permendikbud Number 66 of 2013 concerning Educational Assessment Standards. The purpose of authentic assessment is as follows. 
a. planning of student assessment in accordance with the competencies to be achieved and based on assessment principles,

b. implementation of student assessment in a professional, open, educative, effective, efficient, and in accordance with the sociocultural context; and

c. reporting of student assessment results in an objective, accountable and informative manner Authentic assessment includes three domains of learning outcomes, namely the realm of attitudes, skills, and knowledge. Authentic assessment carried out must be able to describe what attitudes, skills, and knowledge students have or have not, how they apply their knowledge, in what ways they have or have not been able to apply learning gains, and so on. Laelasari states that the character of assessment in authentic assessment activities is not only oriented to the characteristics of the students, but includes the characteristics of the learning method, the curriculum being used, facilities and school administration (Laelasari, 2017, p.100). During the process of learning in class, students not only do or do activities in accordance with the teacher's instructions, but can also show certain desired behaviors according to the formulation of learning objectives. In addition, students are also able to do something related to applications in real life contexts and not only related to the product or the results of a learning process, but include all processes of teaching and learning activities. The difference between traditional assessment and authentic is as Table 1.

Table 1. Differences in Traditional Assessment with Authentic Assessment

\begin{tabular}{cll}
\hline No. & \multicolumn{1}{c}{ Traditional Assessment } & Authentic Assessment \\
\hline 1. & Choose response (selected response) & Doing task \\
2. & Contrived or simulated & Real life \\
3. & Remember / recognize & Construction / application \\
4. & The teacher constructs & Students construct \\
5. & Indirect evidence & Direct evidence \\
\hline
\end{tabular}

\section{Authentic Assessment Techniques}

Authentic assessment is an assessment that requires students to demonstrate knowledge, attitude, skills and abilities in real life situations. A test is said to be authentic, if it requires the ability to apply knowledge, context or real situation, the context according to the student's life, and there is enough information or data for students to apply their knowledge. Furthermore Bolat and Karakus stated that authentic assessment is based on ground of assessment made by students using higher order thinking skills (Bolat \& Karakus, 2017, p.38). Authentic assessment is based on high-level thinking skills. A science teacher can perform authentic assessments with stages or procedures.

a. carried out comprehensively to assess starting from input, process, and output of learning

b. integrated with learning

c. assess students' readiness, process, and learning outcomes as a whole

d. includes the realm of attitude, skill, and knowledge

e. relevant to the scientific approach in learning

f. reflect real-world problems

g. not only measures what is known by students, but rather emphasizes measuring what students can do.

The techniques and instruments used for assessing the attitudes, knowledge and skills competencies are based on Permendikbud, No 104 of
2014 concerning assessment. In an attitude competency assessment, educators conduct attitude competency assessments through observation, selfassessment, peer evaluation by students and journals. The instrument used for observation, selfassessment, and inter-participant assessment is a checklist or ratingscale accompanied by a rubric, while in a journal in the form of educator notes.

Educators assess knowledge competencies through written tests, oral tests, and assignments (Rosana, 2015, p.179). Written test instruments in the form of multiple choices, short answer answers, correct, matching, and descriptions. The description instrument includes scoring guidelines. The form of written test instruments can be done through written test questions, questions and answers, discussions, and observations. Educators assess skills competency through performance appraisal, which is an assessment that requires students to demonstrate a particular competency by using practice tests, projects, and portfolio assessments. The instrument used in the form of a checklist or rating scale equipped with a rubric.

\section{Implementation of Authentic Assessment In Science Learning}

Science is a way of knowing about the world (Chiappeta \& Koballa, 2010, p.102). In a meaningful way, the Directorate General of PMPTK stated that 
science is a study of the natural environment, in this case related to how to systematically find out about nature, so that the science is not only a mastery of a collection of knowledge in the form of facts, concepts, or principles only, but also an invention process (Ditjen PMPTK, 2008, p.21). Based on these two senses it can be stated that science is a number of processes of gathering activities, knowledge gained through certain activities, and characterized by the values and attitudes of scientists using scientific processes in acquiring knowledge.

Application of authentic assessments in science learning needs to adjust the dimensions or domain of the science itself. The four domains of science in the context of natural science learning include: scientific attitudes of science, scientific processes (scientific methods) science, natural science products, and science applications or technology (Sukardjo, 2010, p.7). IPA as an attitude means that IPA can develop because of a diligent, thorough, open and honest attitude. Science as a scientific process means that science is a process or method for gaining knowledge. IPA as a product means that in the Natural Sciences there are facts, laws, principles, and theories that have been accepted. Science as a technology implies that science is related to improving the quality of life. The four elements are the characteristics of a full IPA which actually cannot be separated from each other.

Authentic assessment in science learning is used to assess student learning outcomes from aspects of attitudes, knowledge, and skills. Authentic assessment of attitude competencies is carried out through observation, self assessment, peer assessment and journals. Instruments that can be used in attitude assessment are: observation, selfassessment, and assessment among students in the form of a check list or rating scale with a rubric. In addition, journals can also be used in the form of teacher notes about the strengths, weaknesses, attitudes and behavior of students in and outside the classroom. The flow of application of authentic assessment for attitude aspects as shown in Figure 1.

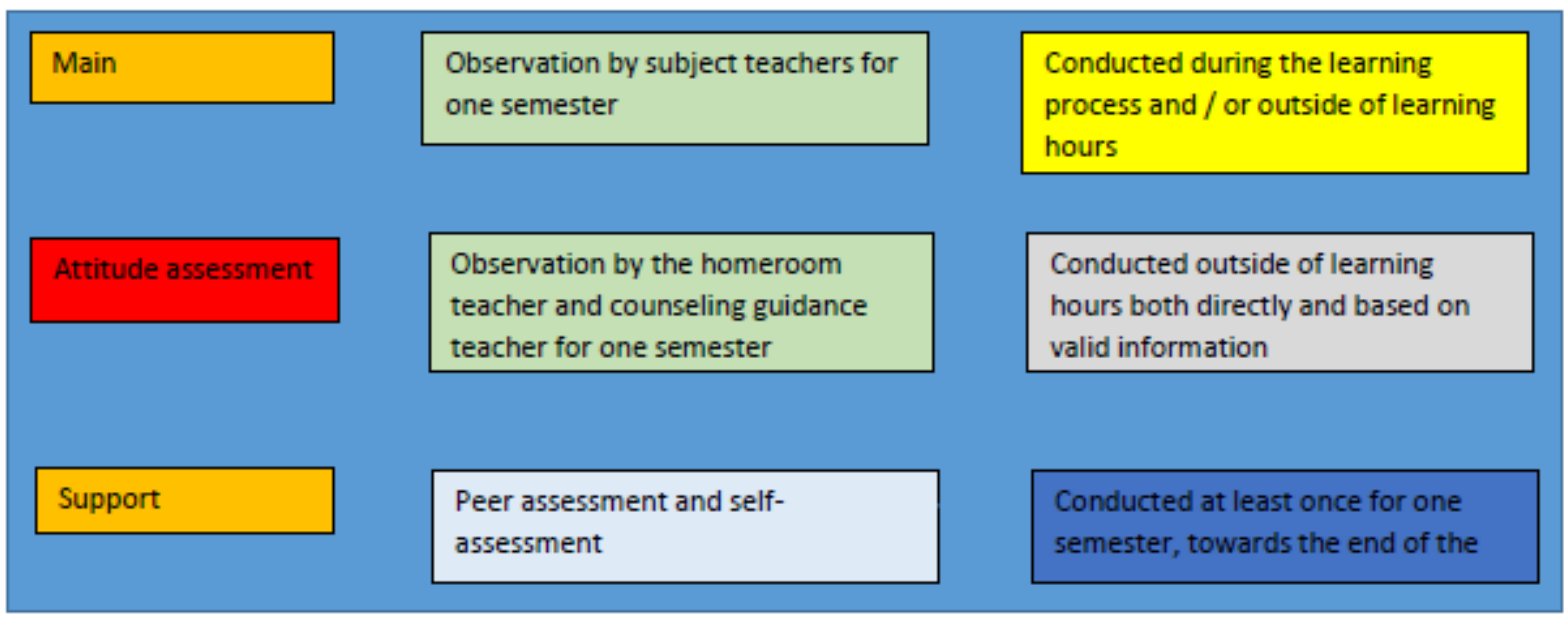

Figure 1. Authentic Assessment Procedure for Attitude Aspects

The attitude assessment plan is carried out based on core competency 1 (KI-1) and core competency 2 (KI-2). The teacher plans and determines the attitudes that will be assessed in learning in accordance with learning activities. In the attitude assessment outside learning the teacher can observe other attitudes that arise naturally. The attitude assessment planning steps are as follows.

a. Determining the attitude that will be developed at school refers to core competency 1 (KI-1) and core competency 2 (KI-2).

b. Determine indicators according to the attitude competencies that will be developed. For example, the attitude to core competency 1 (KI-1) and its indicators can be developed by the school as follows

1) Obedience of worship.
- Obedient behavior in carrying out the teachings of their religion,

- want to invite their classmates to do worship together,

- attend religious activities held by schools,

- carry out worship according to religious teachings, for example: prayer, fasting.

- celebrating religious holidays,

- carry out worship on time and so on.

2) Be thankful.

- behavior accepts characteristic differences as God's grace,

- always accept assignments with an open attitude,

- grateful for the gift of others,

- acknowledge the greatness of God in creating the universe, 
- safeguarding nature, not damaging plants, and so on

For example, the attitude to core competency 2 (KI-

2 ) and its indicators can be developed by the school as follows.

1) Honest.

- don't want to lie or don't cheat,

- do the work given by the teacher himself, without copying the assignments of others,

- do the assessment questions without cheating,

- $\quad$ say exactly what happened or experienced in everyday life,

- want to acknowledge mistakes or mistakes, etc.

2) Discipline.

- follow the rules in school,

- orderly in carrying out task training,

- present at school on time,

- enter class on time,

- wear a complete and neat uniform,

- obey the rules of the school,

- carry out class cleanliness pickets, etc.

c. Designing learning activities that can create predetermined attitudes. In learning, it allows the emergence of attitudes that can be developed in learning. It is intended that the attitude assessment is a behavioral coaching in accordance with character in the framework of the formation of student character. After determining the planning steps, the teacher prepares the observation format to be used in the form of an observation sheet or journal. The indicators that have been formulated are used as a reference for the teacher in making observation sheets or journals

Authentic assessment for aspects of knowledge competence is carried out through written tests, oral tests, and assignments. The test instrument is a set of items. Writing test questions that are often used in schools are multiple choice and descriptions, while oral tests need to be prepared in the form of a list of questions that are delivered directly in the form of questions and answers. Assignment instruments in the form of homework assignments or projects that can be done individually or in groups according to task characteristics. In addition, the instrument for assessing aspects of knowledge must meet the rules of substance (material), construction, and language.

An authenic assessment of skills competency is carried out through performance observations that require students to demonstrate certain competencies, through practice tests, projects, or portfolio assessments. Skill assessment instruments in the form of check lists or rating scales with rubrics. Practice tests require students to do skills in the form of activities that are in accordance with the demands of competence. Projects are tasks that include design, implementation and reporting activities that must be completed within a certain time. Portfolio evaluation is carried out by assessing the collection of students' work in a particular field that is integrative in nature.

Assessment of knowledge and skills can be done separately or integrated. Basically, when the skills assessment is carried out, even a knowledge assessment can be done directly. Assessment of knowledge and skills must refer to basic competency mapping from core competency 3 (KI-3) and core competency 4 (KI-4). The flow of application of authentic assessment for aspects of knowledge and skills as shown in Figure 2.

At this planning stage the steps that must be taken are

a. Mapping of basic competencies (BC) learning content. The mapping of these basic competencies is used as the basis for designing assessment activities both daily, per theme, and per semester. Below are examples of basic competency mapping.

b. Determination of minimum completeness criteria (MCC). Determine the minimum completeness criteria (MCC) by considering the average ability level of students, the complexity of competencies, and the ability of supporting resources including school residents, facilities and infrastructure in the implementation of learning. The education unit is expected to continuously improve the learning completeness criteria to achieve the ideal completeness criteria.

c. Designing Forms and Assessment Techniques. This form of assessment is designed based on the results of the basic competencies (BC) mapping that has been done. Each form of assessment requires a different instrument. If the form of test assessment is the instrument in the form of items. If the assessment form is non-test, the instrument can be a check list or rubric.

d. Design of Assessment Instruments. The assessment instrument is a measuring instrument used to assess / measure the achievement of students' competencies, the type of instrument chosen according to the form of assessment.

After the selese planning stage, it enters the implementation phase. The implementation phase begins with a form of assessment that will be applied both written, performance, and project tests. The development of written tests begins with the preparation of the question box based on the results of the analysis of core competency (KI) and (BC-3). The lines prepared by the teacher are then used as questions that will be used for assessment for aspects 
Didik Setyawarno, Atik Kurniawati/ JSER 2018, 2(2), 53

of knowledge. Performance and project assessments can be done with the help of an assessment rubric. The processing stage is carried out after the assessment instrument has been applied to students, in order to obtain student value data. The student value data is processed so that it can be taken into consideration in giving a decision whether it has met the determination of minimum completeness (MCC) or the need for remedial activities. In addition skills assessment techniques if carried out separately can be described in Figure 3.

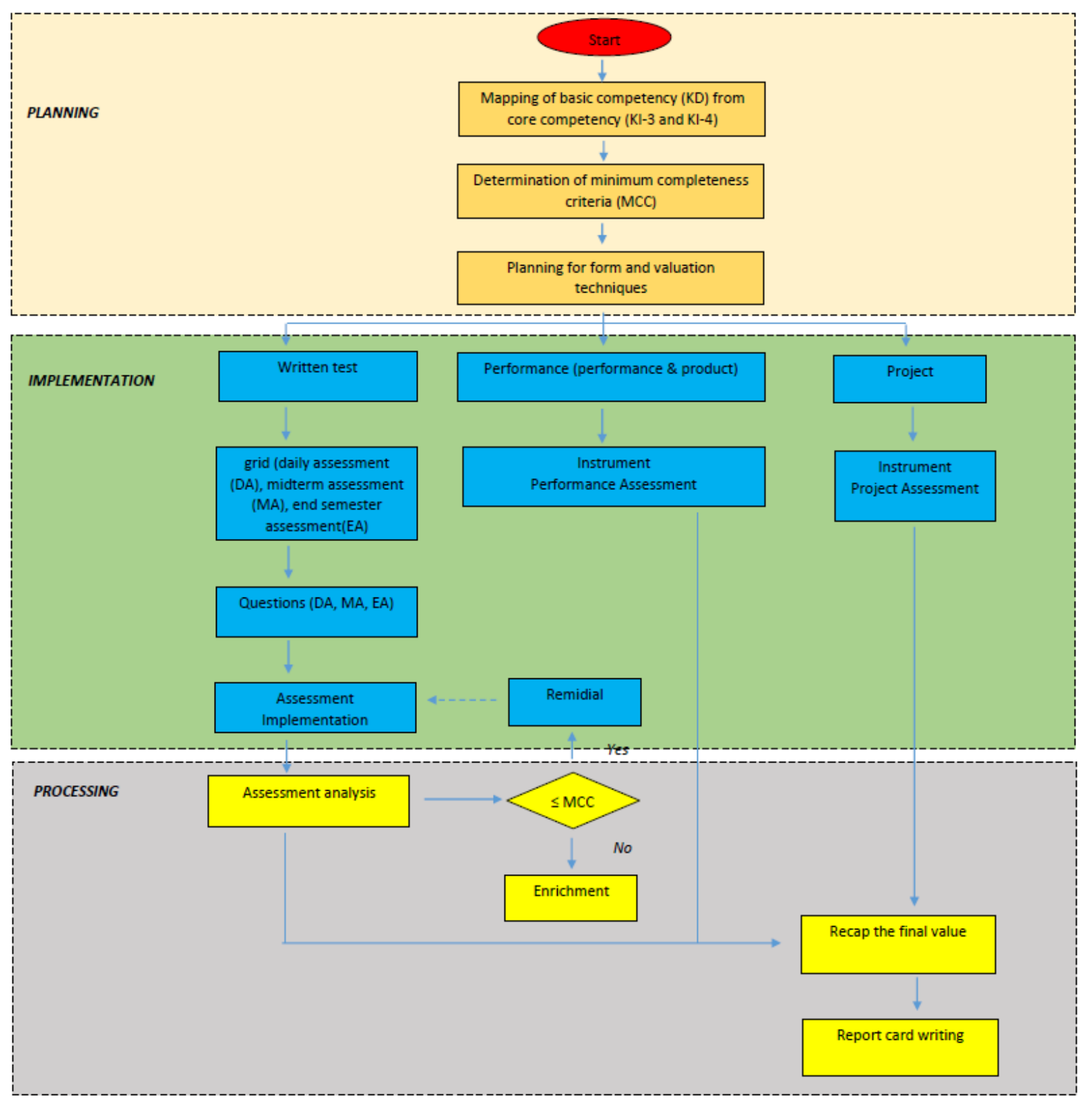

Figure 2. Authentic Assessment Procedures for Aspects of Knowledge and Skills 


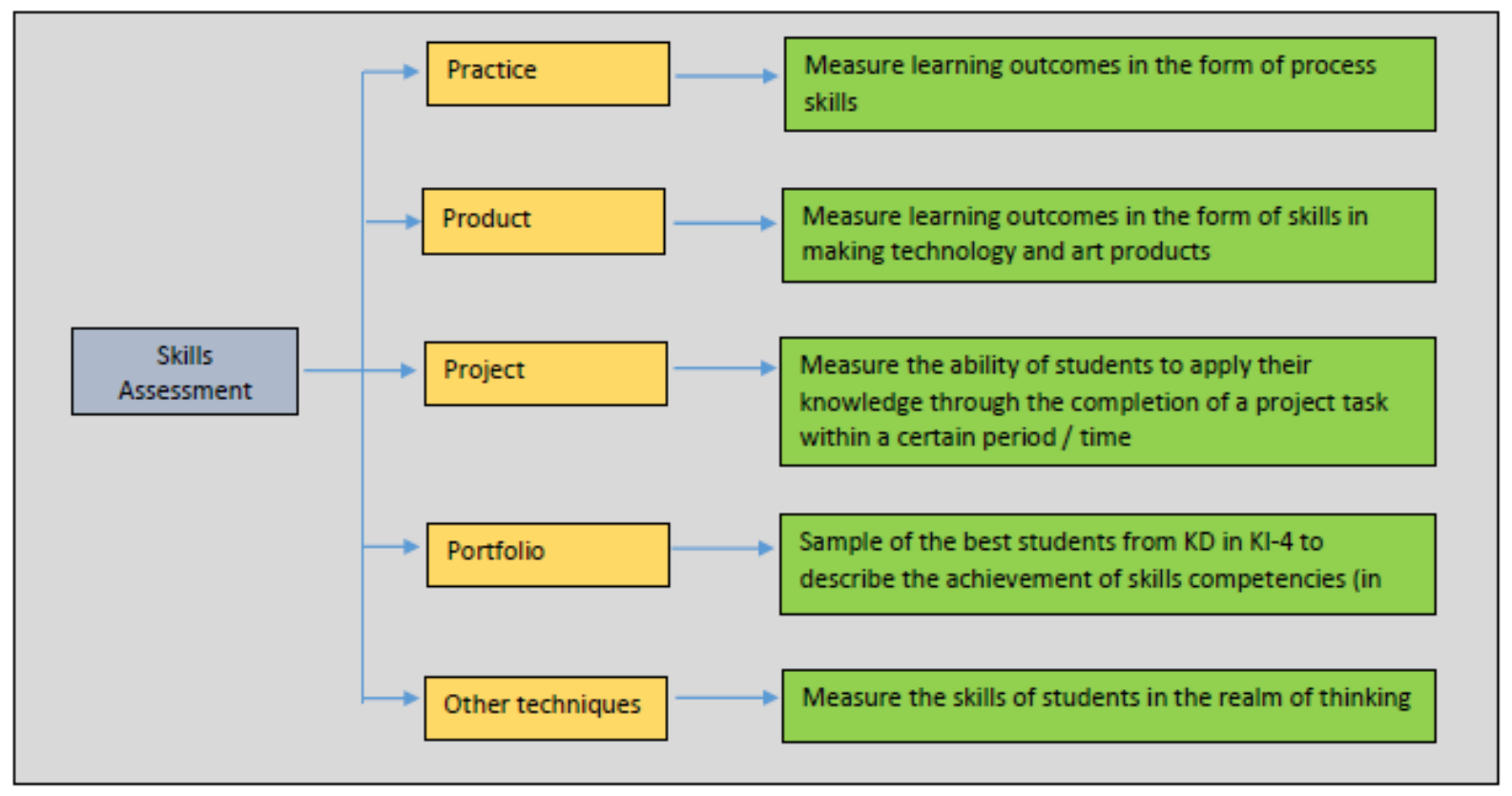

Figure 3. Authentic Assessment Procedures for Skills Aspects

\section{CONCLUSION}

Authentic assessment is basically an assessment of all aspects of attitudes, knowledge, and skills. This aspect of description is elaborated from the core competency (CC) and basic competency (BC) in the 2013 curriculum. Various assessment techniques and instruments need to be developed both tests and nontests such as performance appraisals or assignments. Authentic assessment is very appropriate to be applied in the context of natural science learning, because it fits and fulfills all aspects of the dimension or domain of the Natural Science itself.

Authentic assessment in science learning is deemed necessary to be applied in the science material at school. Science Education students, science teachers, and observers of Natural Sciences are expected to be able to develop authentic assessment instruments in science learning in the classroom.

\section{REFERENCES}

Anderson, Lorin W \& Krathwohl. (2001). A taxonomy for Learning, Teaching and Assessing a Revision of Blooms Taxonomy of Educational Objetives. USA, New York: Longman.

Bolat, Yeliz \& Karakus, Memet. (2017). Design Implementation and Authentic Assessment of a Unit According to Concept-Based Interdisciplinary Approach. International Electronic Journal of Elemtary Education Volume 10, Issue 1.

Dadan Rosana. (2015). Evaluasi Pembelajaran Sains. Yogyakarta: UNY Press.
Dadan Rosana \& Didik Setyawarno. 2016. Statistik Terapan untuk Penelitian Pendidikan. Yogyakarta: UNY Press.

Depdiknas. (2008). Strategi Pembelajaran MIPA. Jakarta: Direktorat Tenaga Kependidikan Direktorat Jenderal Peningkatan Mutu Pendidik Dan Tenaga Kependidikan.

Didik Setyawarno. (2018). Panduan Praktikum Teori Respon Butir. Yogyakarta: FMIPA UNY.

Didik Setyawarno \& Zuhdan Kun Prasetyo. 2016. Development of Indonesian Qualification Framework (IQF) Level 6 Of Physics Education. Proceeding Of 3rd International Conference on Research, Implementation And Education Of Mathematics And Science Yogyakarta, 16 - 17 May 2016.

Fook, Chan Yuen \& Sidhu, Gurnam Kaur. (2010). Authentic Assessment and Pedagogical Strategies in Higher Education. Journal of Social Sciences Vol. VI, No. 2.

Gulikers, Judith T.M; Bastiaens; Theo J; \& Kirschner, Paul A. (2004). Perceptions of Authentic Assessment Five Dimensions of Authenticity. Open University of the Netherlands.

Mueller, Jon. (2005). The Authentic Assessment Toolbox: Enhancing Student Learning through Online Faculty Development. Journal of Online Learning and Teaching, Vol. 1, Number 1.

Kemdikbud. (2017). Panduan Penilaian oleh Pendidik dan Satuan Pendidikan Sekolah Menengah Pertama. Jakarta: Direktorat Jenderal Pendidikan Dasar dan Menengah Direktorat Pembinaan Sekolah Menengah Pertama.

Kemdikbud. (2015). Panduan Penilaian untuk Sekolah Dasar. Jakarta: Direktorat Jenderal 
Pendidikan Dasar dan Menengah Direktorat Pembinaan Sekolah Dasar.

Kemdikbud. (2015). Panduan Penilaian untuk Sekolah Menengah Atas. Jakarta: Direktorat Jenderal Pendidikan Dasar dan Menengah Direktorat Pembinaan Sekolah Menengah Atas.

Laelasari. (2007). Penilaian Autentik dalam Pembelajaran Matematika. Jurnal LP3M Universitas Sarjanawiyata Tamansiswa Yogyakarta: Sosiohumaniora, Vol.3, No.2.

Majid, Ilham, \&Ika A. (2012). Penerapan Penilaian Autentik untuk Meningkatkan Hasil Belajar Siswa Pada SMP N 7 Kota Ternate. Jurnal Bioedukasi, Vol. 1 No.1.

Ma'ruf \& Andi Lenny Rahim. (2008). Pengembangan Perangkat Penilaian Autentik dalam Pembelajaran Fisika untuk Meningkatkan Motivasi Partisipasi dan Hasil Belajar Fisika Siswa Kelas X SMA Negeri 1 Pangkajene. JPF Volume I Nomor 3.

Nyoman Dantes. (2018). Hakikat Asesmen Otentik sebagai Penilaian Proses dan Produk dalam Pembelajaran yang Berbasis Kompetensi. Makalah disampaikan pada In House Training (IHT) SMA N 1 Kuta Utara.
Peraturan Menteri Pendidikan dan Kebudayaan Republik Indonesia Nomor 66 Tahun 2013 Tentang Standar Penilaian Pendidikan.

Peraturan Menteri Pendidikan dan Kebudayaan Republik Indonesia Nomor 104 Tahun 2014 Tentang Penilaian Hasil Belajar oleh Pendidik pada Pendidikan Dasar dan Pendidikan Menengah.

Peraturan Menteri Pendidikan Dan Kebudayaan Republik Indonesia Nomor 58 Tahun 2014 Tentang Kurikulum 2013 Sekolah Menengah Pertama/ Madrasah Tsanawiyah.

Pusat Kurikulum. (2011). Panduan Pengembangan Pembelajaran IPA Terpadu. Jakarta: Balitbang Depdiknas.

Siti Fatonah, PujiatiSuyata, \& Zuhdan Kun Prasetyo. 2013. Developing an Authentic Assessment Model in Elementary School Science Teaching. Journal of Education and Practice Vol.4, No.13.

Tutut Widowati, Nonoh Siti Aminah, \& Cari. (2016). Pengembangan Instrumen Penilaian Otentik Berbasis Scientific Literacy Pada Pembelajaran Fisika di SMA sebagai Implementasi Kurikulum 2013. Jurnal Inkuiri, Vol 5, No. 2. 